\title{
Abiding Effects of Phenolic Antioxidants on Oxidative Behaviour of Fatty Acid Methyl Esters Derived from Waste Cooking Oil
}

\author{
Mosharof Hossain, ${ }^{\mathrm{a}, \mathrm{b}}$ Shah Mohammad Asaduzzaman Sujan, ${ }^{\mathrm{a}, \mathrm{b}}$ Mohammad Shah Jamal, ${ }^{\mathrm{b}}$

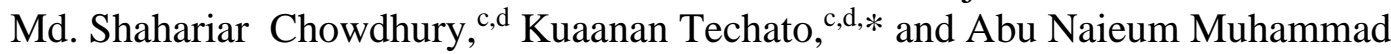 \\ Fakhruddin ${ }^{\mathrm{a}}$ *
}

\begin{abstract}
Fatty acid alkyl esters (FAMEs) derived from waste vegetable oils and nonedible oil sources are the most attractive alternative liquid biofuel in the energy field. Substitute methyl esters derived from waste cooking oil (WCO) have a lower induction period ( $3.12 \mathrm{~h})$ and do not satisfy the Biodiesel EN 14214:2012 Standard ( $8 \mathrm{~h}$ ). In this study, concentrations of $100,250,500$, and $1000 \mathrm{ppm}$ of four different types of phenolic antioxidants-butylated hydroxyanisole (BHA), butylated hydroxytoluene (BHT), tert-butyl hydroquinone (TBHQ), and propyl gallate (PG)-were used to examine oxidative stability and improve fuel quality. PG $(250 \mathrm{ppm})$ showed the most effective result of $18 \mathrm{~h}$ to $12.17 \mathrm{~h}$ of the induction period of 6 months of storage. Antioxidant effectiveness increased with regard the oxidative stability of waste cooking oil methyl ester in the following order: $\mathrm{BHT}<\mathrm{TBHQ}$ $<\mathrm{BHA}<\mathrm{PG}$. Acid value and kinematic viscosity of WCO biodiesel increase $564.3 \%$ and $10.3 \%$ respectively, which indicate degradation of fuel quality. But biodiesel with antioxidant, all the parameters changes dynamically. The acid value, kinematic viscosity, and density of all investigated samples increased. All results were within limits of EN 14214:2012 standard specification for the 6 months of storage period.
\end{abstract}

Keywords: Antioxidants; Storage behavior; Oxidative stability; Rancimat test; Waste cooking oil: Fatty acid methyl ester

Contact information: a: Department of Environmental Sciences, Jahangirnagar University, Savar, Dhaka1342, Bangladesh; b: Institute of Fuel Research and Development, Bangladesh Council of Scientific and Industrial Research(BCSIR), Dhaka-1205, Bangladesh; c: Faculty of Environmental Management, Prince of Songkla University, 15 Karnjanavanich Rd., HatYai, Songkhla Thailand 90110; d: Environmental Assessment and Technology for Hazardous Waste Management Research Centre, Faculty of Environmental Management, Prince of Songkla University, 15 Hat Yai, Songkhla Thailand, 90110;

*Corresponding authors: Kuaanan.t@psu.ac.th,fakhruddin@juniv.edu

\section{INTRODUCTION}

Fossil fuel reduction, environmental concern, and unbalanced crude oil prices have increased the need for alternatives to fossil fuels. Additionally, climate change and other ecological risks have prompted all nations to diminish their reliance on fossil fuel (Ramaraju and Kumar 2011; Alam et al. 2017). Biodiesel is a sustainable, biodegradable, and eco-friendly elective fuel that is used as a substitute for petroleum-based diesel (Hossain et al. 2014; Saluja et al. 2016). Biodiesel is a blend of mono-alkyl esters of longchain saturated or unsaturated fats. Biodiesel is produced from renewable lipids reacted with different types of straight-chain low carbon alcohol (methanol, ethanol, or propanol) in the presence or absence of homogeneous or heterogeneous catalyst (Demirbas 2009; 
Atabani et al. 2012; Kafuku and Mbarawa 2013).

Raw materials are a vital issue for biodiesel use in the commercial sector. Due to food security, researchers have preferred the use of non-edible oils such as jatropha seed, rubber seed, and Karanja seed oil together with waste cooking oil as a potential feedstock for biodiesel production (Ramaraju and Kumar 2011; Hossain et al. 2014; Khalid et al. 2014; Alam et al. 2017). In this study, waste cooking oil from different restaurants in Dhaka, Bangladesh, was collected for biodiesel production. A fast-growing and highly populated country like Bangladesh produces a considerable amount of waste cooking oil per day. Waste cooking oil has massive advantages over other sources such as low cost and availability, but it has also some demerits such as the fact that it contains higher percentage of free fatty acid and there is a chance to produce soap during transesterification.

Low volatility and high viscosity are the main two reasons to not use lipids (vegetable oil or animal fats) directly in the internal combustion engine system (Knothe $e t$ al. 2005; Atabani et al. 2012). To overcome these problems, vegetable oils or animal fats are reacted with straight-chain simple alcohols such as methanol to produce fatty acid methyl esters (FAME), which are also known as biodiesel. Conversion methods include pyrolysis, and trans-esterification. Trans-esterification is the best route with minimal engine complications (Knothe et al. 2005; Gupta et al. 2007; Shahid and Jamal 2011).

Biodiesel has tremendous advantages over petro-diesel, such as excellent lubricity, high flash point, low toxic emissions, biodegradability, and environmental compatibility (Knothe et al. 2005; Balat and Balat 2010). Biodiesel fuel qualities, according to the standard (EN 14214 (2012)), are the main criteria for the commercial introduction in the transport sector to ensure customer acceptance. Storage stability is one of the main factors that decide the quality of biodiesel. Biodiesel fuel properties that decline during storage cause more severe problems than in the case of commercial diesel fuel. Resistance to fuel degradation is the most critical issue during storage for the competitive utilization of biofuel in the retail liquid fuel sector.

During long-term storage, contact with air and other pro-oxidizing conditions cause the oxidation of unsaturated fatty acid methyl esters in biodiesel. Bondioli et al. (1995) and Thompson et al. (1998) investigated the degradation behaviour of rapeseed oil methyl esters (RME) under different storage conditions; all oxidative actions such as acid value, peroxide value, and viscosity increased with time in storage. Viegas et al. (2018) and Simkovsky and Ecker (1999) investigated the interrelationship between oxidative biodiesel stability and natural antioxidant tocopherol. The rate oxidation of fatty acid methyl ester compounds depends on the number of double bonds and their position in the fatty acid linear chain structure (Frankel 2014). The relative oxidation rates for these unsaturated long-chain esters follow the order of linolenic > linoleic > oleic (March 1992). The positions that are allylic to double bonds are the leading positions where oxidation chain reactions are usually initiated. Fatty acid methyl esters contain methylene-interrupted double bonds [(9Z, 12Z)-octadecadienoic acid, which goes by the common name linoleic acid] and [(9Z,12Z,15Z)-octadecatrienoic acid, which is linolenic acid] are susceptible to oxidation because of their double bonds position in the long carbon chain body. The oxidation of biodiesel (fatty acid methyl ester) is also affected by other factors, such as prominent temperature, light energy, presence of different types of residual metals, and other parameters that may speed up oxidation reactions (Monyem et al. 2000; Mittelbach and Gangl 2001).

Oxidation reactions of biodiesel are usually polymerization reactions, in which primary and secondary products (peroxides, acids, aldehydes and keto compounds, 
alcohols) and high molecular weight final products are formed. The high molecular weight (mainly solid) products may cause some problems in engine systems such as filterblocking, injector failure, and deposit formation (Waynick 2005; Paligová et al. 2008). The use of phenolic antioxidant species slows the degradation rate and enhances oxidative fuel stability to meet the biodiesel standard (Hossain et al. 2013). A minimum of $8 \mathrm{~h}$ oxidation stability is mandatory for biodiesel transport applications corresponding to the European Standard (EN14214 (2012)). Thus, biodiesel samples derived from different sources ought to satisfy the existing requirements and specifications for potential commercial use in the automobile sector. FAME with added antioxidants must be investigated for oxidative stability. Acid value, kinematic viscosity, and density should be checked during the storage period. Antioxidants that have been widely studied for commercialization of biodiesel include butylated hydroxyanisole (BHA), butylated hydroxytoluene (BHT), tert-butyl hydroquinone (TBHQ), and propyl gallate (PG).

Loh et al. (2006) examined the oxidative stability on used palm oil biodiesel for 5 weeks. Maia et al. (2011) reported that TBHQ and BHT enhance the oxidation stability of soybean biodiesel on the storage condition. Tang et al. (2008) found that $1000 \mathrm{ppm}$ concentration of all tested antioxidants (TBHQ, PG, PY, BHA, BHT) were adequate to increase oxidation stability to the required value. The effectiveness order found by these authors is TBHQ $>$ BHA $>$ PY $>$ BHT $>$ PG for soybean biodiesel and TBHQ $>$ PY $>$ PG for cotton seed biodiesel. Karavalakis et al. (2011) inspected the oxidation stability and storage stability of commercially available biodiesel samples with TBHQ, PG, PY, BHA, and BHT synthetic antioxidants at $3000 \mathrm{ppm}$ concentration. They observed the order of efficiency as TBHQ $>$ PG $>$ PY $>$ BHA $>$ BHT. Ferrari et al. (2005) observed that TBHQ is the most effective antioxidant among TBHQ, BHA, and BHT on soybean biodiesel oxidation stability. Yang et al. (2017) found the effectiveness order as TBHQ $>$ PG $>$ BHT $>$ BHA for the improvement of camelina biodiesel oxidation stability and storage stability.

Nevertheless, research on long-term storage behavior is necessary for commercialization. This research determined the potential of different commercial synthetic phenolic antioxidants for enhancing the oxidation stability of biodiesel. Other parameters such as acid value, kinematic viscosity, and density were investigated during the storage period to commercialize waste cooking oil biodiesel. Further, the study sought to identify appropriate additive and appropriate concentration that might notably improve biodiesel's stability to satisfy the specification at prolonged storage. These studies also determine the correlation with oxidation stability, acid value, kinematic viscosity, and density during 6 months of storage conditions with and without antioxidant biodiesel.

\section{EXPERIMENTAL}

\section{Materials}

Waste cooking oil (WCO) was collected from four different local restaurants in Dhaka City, as shown in Table 1. Potassium hydroxide for acid value determination and sodium hydroxide for transesterification was purchased from Merck (Frankfurt, Darmstadt, Germany). Sulfuric acid (99.8\%) and methanol (99.5\%) were purchased from Merck for esterification and transesterification, respectively. The BHT, TBHQ, BHA, and PG (Fig. 1) antioxidants were purchased from Sigma-Aldrich (St. Louis, MO, USA). 
<smiles>Cc1cc(C(C)(C)C)c(O)c(C(C)(C)C)c1</smiles>

2,6- ditert-butyl-4-methyl phenol (BHT)<smiles>COc1ccc(O)cc1C(C)(C)C</smiles><smiles>COc1ccc(O)c(C(C)(C)C)c1</smiles>

3-tert-butyl-4-hydroxyanisole (BHA)<smiles>CC(C)(C)c1cc(O)ccc1O</smiles>

tert-butyl hydroquinone (TBHQ)<smiles>CCCOC(=O)c1cc(O)c(O)c(O)c1</smiles>

n-propyl gallate $(\mathrm{PG})$

Fig. 1. Structure of different antioxidants

Table 1. Restaurant Name and Experimental Code

\begin{tabular}{|c|c|c|}
\hline SI. No. & Restaurant name & Code \\
\hline 01. & Vozon Bilash & WCOR-1 \\
\hline 02. & FFC & WCOR-2 \\
\hline 03. & Amtola & WCOR-3 \\
\hline 04. & The Kitchen & WCOR-4 \\
\hline
\end{tabular}

\section{Waste Cooking Oil Characterization}

The WCO from different restaurants were different dark colors with solid suspended materials, as shown in Fig. 2. Before filtering raw materials, the amount of solid suspended materials in the oil matrix was measured. The acid value was determined for next the experimental step, as presented in Table 2.

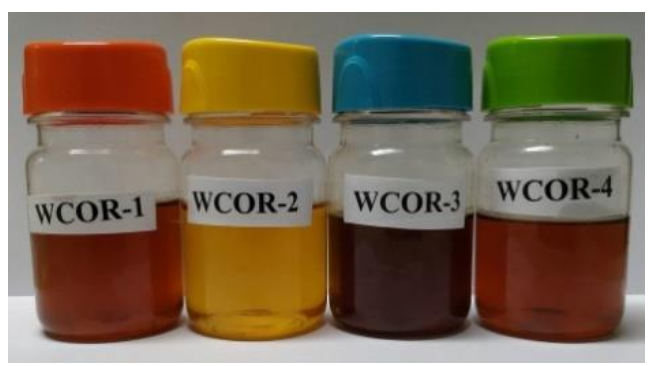

Fig. 2. Colour of different waste cooking oil raw materials

Table 2. Solid Materials and Acid Value of Raw Materials

\begin{tabular}{|l|l|l|l|}
\hline SI. No. & Code Name & Solid Materials $(\mathrm{w} / \mathrm{w} \%)$ & Acid Value $(\mathrm{mgKOH} / \mathrm{g})$ \\
\hline 01. & R-1 & 1.08 & 26.77 \\
\hline 02. & R-2 & 0.42 & 22.43 \\
\hline 03. & R-3 & 1.75 & 37.38 \\
\hline 04. & R-4 & 1.12 & 25.15 \\
\hline
\end{tabular}


Based on the data in Table 2, WCOR-3 was selected for biodiesel production because of its high acid value. All coded samples had similar fatty acid methyl ester composition, as shown in Table 3. FAME composition is essential for storage measurement, and WCOR-3 was selected for this present work based on Fig. 2, Table 2, and Table 3 data. WCOR-3 is labeled as WCO.

Table 3. FAME Composition of WCOR-1, WCOR-2, WCOR-3, and WCOR-4

\begin{tabular}{|l|l|l|l|l|l|l|l|l|l|l|}
\hline & \multicolumn{7}{|c|}{ Composition Weight (\%) } & \\
\hline Sample ID & c12:0 & c14:0 & c16:0 & c16:1 & c18:0 & c18:1 & c18:2 & c18:3 & c20:0 & Neat FAME \\
\hline wcor-1 & n.d. & 1.09 & 42.34 & n.d. & 3.58 & 41.52 & 8.57 & 0.43 & n.d. & 97.53 \\
\hline wcor-2 & 0.21 & 0.88 & 40.52 & 0.33 & 0.30 & 46.16 & 8.65 & 0.11 & 0.20 & 97.36 \\
\hline wcor-3 & 0.24 & 0.90 & 40.67 & 0.37 & 0.32 & 46.16 & 8.85 & 0.15 & 0.30 & 97.96 \\
\hline wcor-4 & 0.24 & 0.93 & 41.01 & 0.51 & n.d. & 45.95 & 8.48 & 0.20 & 0.36 & 97.68 \\
\hline
\end{tabular}

${ }^{*}$ n.d. $=$ not detected

\section{Biodiesel Production}

After the filtration of the WCO, FAME was prepared using a dual step reaction (acid-catalyzed esterification and alkaline-catalyzed transesterification) due to the presence of higher free fatty acids percentage in the raw materials. Esterification and transesterification reactions were carried out in a $1 \mathrm{~L}$ bioreactor equipped with three necks, a condenser to recover methanol, a magnetic stirrer, a water bath, a thermometer, and a sampling outlet for biodiesel production.

\section{Esterification}

In the esterification process, $\mathrm{H}_{2} \mathrm{SO}_{4}$ was dissolved in alcohol using a standard agitator and adding $\mathrm{WCO}$ in the mixture. The reaction mixture was transferred into a $1 \mathrm{~L}$ bioreactor and maintained reaction condition for $400 \mathrm{rpm}$ stirring speed at $60{ }^{\circ} \mathrm{C}$ for $1 \mathrm{~h}$. The mixture was settled for $1.5 \mathrm{~h}$, and the methanol-water-catalyst fraction from the top layer of the separating funnel was removed (Alam et al. 2017). The lower part of the mix was then collected, and the free fatty acid (FFA) percentage was measured. If the FFA\% was reduced to less than $2 \%$, then the next transesterification reaction step was carried out for biodiesel preparation.

\section{Transesterification}

In this step, the base catalyst $\mathrm{NaOH}$ was dissolved in methanol. Then esterified WCO was added to it. The prepared mixture was set for transesterification reaction using the same bioreactor. The reaction conditions $60{ }^{\circ} \mathrm{C}$ for $1.5 \mathrm{~h}$ and $400 \mathrm{rpm}$ stirring speed were maintained. The final product was transferred to a separating funnel for $24 \mathrm{~h}$ to separate the upper layer of WCOME from the lower layer of glycerol. WCOME was washed several times with warm distilled water $50 \%\left(\mathrm{v} / \mathrm{v}\right.$ oil) at $60{ }^{\circ} \mathrm{C}$ to remove the impurities, methanol, $\mathrm{NaOH}$, and glycerol. Water and methanol were removed from WCOME using a rotary evaporator. Finally, FAMEs were obtained.

\section{Analysis of Biodiesel (FAME) Composition}

A GC-FID (Agilent 6890N, column: HP-1, length of a column: $60 \mathrm{~m} \times 0.25 \mathrm{~mm} \times$ $0.25 \mu \mathrm{m}$; Santa Clara, USA) was used to quantify and identify FAME composition according to biodiesel standard (EN 14103 (2011)). 


\section{Storage Sample Preparation of WCO Biodiesel}

TBHQ, PG, BHA, and BHT were used as antioxidants for long-term storage in the darkroom at $21{ }^{\circ} \mathrm{C}$. Each antioxidant was added at 100, 250, 500, and $1000 \mathrm{ppm}$ concentration with biodiesel, and all samples were kept in bottles with sealed lids.

\section{Oxidative Stability Determination}

Oxidation stability of WCO biodiesel was determined as an induction period measured by Rancimat instrument (Metrohm, Rancimat 783, Switzerland) under $110{ }^{\circ} \mathrm{C}$ heating block temperature and $10 \mathrm{~L} / \mathrm{h}$ constant airflow rate according to standard (EN 14112 (2012)). Approximately $3 \mathrm{~g}$ of fresh antioxidant containing WCO biodiesel fuel sample was analyzed with $60 \mathrm{~mL}$ of deionized water and set to 1.5 temperature correction factor $(\Delta T)$. The experiment was conducted every month for a period of 6 months. The acid value was determined of all tested WCO biodiesel samples according to recommended procedure (ASTM D664 - 18e2 (2018)). Density (@ $25^{\circ} \mathrm{C}$ ) and Viscosity (@ $40{ }^{\circ} \mathrm{C}$ ) were measured according to standard method (ASTM D4052-18a (2018) and ASTM D445-19a (2019)).

\section{RESULTS AND DISCUSSION}

\section{Physical Properties}

The physical properties of WCO biodiesel and the test methods used are shown in Table 4. WCO biodiesel exhibited lower oxidative stability of $3.12 \mathrm{~h}$ and did not measure up to biodiesel according to the European Standard (EN 14214 (2012)) regarding oxidation stability.

Table 4. Physical Properties of WCO Biodiesel

\begin{tabular}{|l|l|l|l|l|}
\hline Parameters & Units & Results & EN14214, 2012 & Test method \\
\hline Viscosity @ $40^{\circ} \mathrm{C}$ & $\mathrm{cSt}$ & 4.62 & $3.50-5.00$ & ASTM D445-19a, 2019 \\
\hline Oxidation stability & $\mathrm{h}$ & 3.12 & $8.0 \mathrm{~min}$ & EN 14112, 2012 \\
\hline Acid value & $\mathrm{mgKOH} / \mathrm{g}$ & 0.28 & $0.50 \mathrm{max}$ & ASTM D664-18e2, 2018 \\
\hline Pour point & ${ }^{\circ} \mathrm{C}$ & 16.0 & - & ASTM D97-17b, 2017 \\
\hline Density @ $25^{\circ} \mathrm{C}$ & $\mathrm{kg} / \mathrm{m}^{3}$ & 865 & $860-900$ & ASTM D4052-18a, 2018 \\
\hline Calorific value & $\mathrm{KJ} / \mathrm{kg}$ & 39,070 & - & ASTM D240-19, 2000 \\
\hline Flashpoint & ${ }^{\circ} \mathrm{C}$ & 112 & $120 \mathrm{~min}$ & ASTM D93-20, 1980 \\
\hline
\end{tabular}

FAME composition effect on oxidation stability

The FAME composition and oxidation stability of WCOME were compared with other FAME, such as fish oil methyl ester (FOME) (Hossain et al. 2010). Table 5 compares the FAME compositions and the oxidation stability of WCOME and FOME.

FAME is prone to become oxidized due to the remarkable number of double bonds present in the carbon chain. FOME shows $0.1 \mathrm{~h}$ oxidation stability, whereas WCOME shows $3.12 \mathrm{~h}$ due to more polyunsaturated FAMEs in FOME (28.2\%) than in WCOME (Hossain et al. 2010). 
Table 5. Comparison of FAME Compositions of WCOME and FOME

\begin{tabular}{|c|c|c|}
\hline FAME Component & WCOME & FOME \\
\hline C12:0 & 0.24 & 0.1 \\
\hline C14:0 & 0.90 & 4.5 \\
\hline C16:0 & 40.67 & 17.9 \\
\hline C16:1 & 0.37 & 7.1 \\
\hline C18:0 & - & 1.4 \\
\hline C18:1 & 0.32 & 4.7 \\
\hline C18:2 & 46.16 & 23.8 \\
\hline C18:3 & 8.85 & 3.3 \\
\hline C18:4 & 0.15 & 1.0 \\
\hline C20:0 & 0.30 & 0.3 \\
\hline C20:1 & - & 5.9 \\
\hline C20:3 & - & 1.5 \\
\hline C20:5 & - & $\mathbf{8 . 0}$ \\
\hline C22:0 & - & 0.2 \\
\hline C22:5 & - & $\mathbf{2 . 4}$ \\
\hline C22:6 & - & $\mathbf{1 6 . 3}$ \\
\hline C24:0 & - & 0.2 \\
\hline Oxidation stability (h) & $\mathbf{3 . 1}$ & $\mathbf{0 . 1}$ \\
\hline
\end{tabular}

Antioxidant effect on FAME composition during storage time

Table 6 shows that unsaturated: 3 FAME in WCO biodiesel decreased to $0 \%$ after storage time. Unsaturated: 2 remarkably decreased in fresh biodiesel and biodiesel with BHT. This result rapidly changed after adding antioxidant species in the biodiesel. PG, BHA, and TBHQ showed similar results. Therefore these three antioxidants could suppress the oxidation reaction of WCO biodiesel. No significant effect was found after the addition of BHT when measuring the FAME composition at the end of the storage period. The C16:0 and C18:1 FAME components remained at levels of 40.41\% and 46.09\% after oxidation in WCO biodiesel with PG. These amounts were very similar in quantity with WCO biodiesel before oxidation. PG, BHA, and TBHQ, showed a strong effect against WCO biodiesel oxidation.

Table 6. FAME Composition of Neat WCO Biodiesel at End of Storage Period

\begin{tabular}{|l|l|l|l|l|l|l|l|l|l|l|l|}
\hline & \multicolumn{7}{|c|}{ Composition Weight (\%) } & \\
\hline $\begin{array}{l}\text { Storage } \\
\text { condition }\end{array}$ & $\mathrm{C12:0}$ & $\mathrm{C} 14: 0$ & $\mathrm{C} 16: 0$ & $\mathrm{C} 16: 1$ & $\mathrm{C} 18: 0$ & $\mathrm{C} 18: 1$ & $\mathrm{C} 18: 2$ & $\mathrm{C} 18: 3$ & C20:0 & $\begin{array}{l}\text { Neat } \\
\text { FAME }\end{array}$ \\
\hline $\begin{array}{l}\text { Fresh } \\
\text { biodiesel }\end{array}$ & 0.24 & 0.90 & 40.67 & 0.37 & 0.32 & 46.16 & 8.85 & 0.15 & 0.30 & 97.96 \\
\hline $\begin{array}{l}\text { Stored without } \\
\text { antioxidant }\end{array}$ & 0.21 & 0.88 & 38.12 & 0.33 & 0.34 & 43.67 & 4.02 & - & 0.28 & 87.85 \\
\hline $\begin{array}{l}\text { Biodiesel with } \\
\text { BHT }\end{array}$ & 0.22 & 0.85 & 39.02 & 0.34 & 0.32 & 44.05 & 5.56 & - & 0.26 & 90.62 \\
\hline $\begin{array}{l}\text { Biodiesel with } \\
\text { BHA }\end{array}$ & 0.24 & 0.90 & 39.92 & 0.33 & 0.35 & 45.97 & 7.67 & - & 0.28 & 95.66 \\
\hline $\begin{array}{l}\text { Biodiesel with } \\
\text { PG }\end{array}$ & 0.24 & 0.89 & 40.41 & 0.36 & 0.31 & 46.09 & 8.19 & - & 0.27 & 96.76 \\
\hline $\begin{array}{l}\text { Biodiesel with } \\
\text { TBHQ }\end{array}$ & 0.24 & 0.86 & 39.55 & 0.35 & 0.31 & 45.91 & 6.83 & - & 0.28 & 94.33 \\
\hline
\end{tabular}

Storage condition: Temperature $21^{\circ} \mathrm{C}$; Time 6 months; antioxidant concentration $1000 \mathrm{ppm}$. 
Antioxidant effect on oxidation stability

Treatment with antioxidants for enhancing oxidative stability is necessary to enable WCO biodiesel to become competitive and satisfy the Standard Specification (EN14214 (2012)). The results of antioxidant treatments on the storage stability of WCO biodiesel for 6 months are shown in Fig. 3.
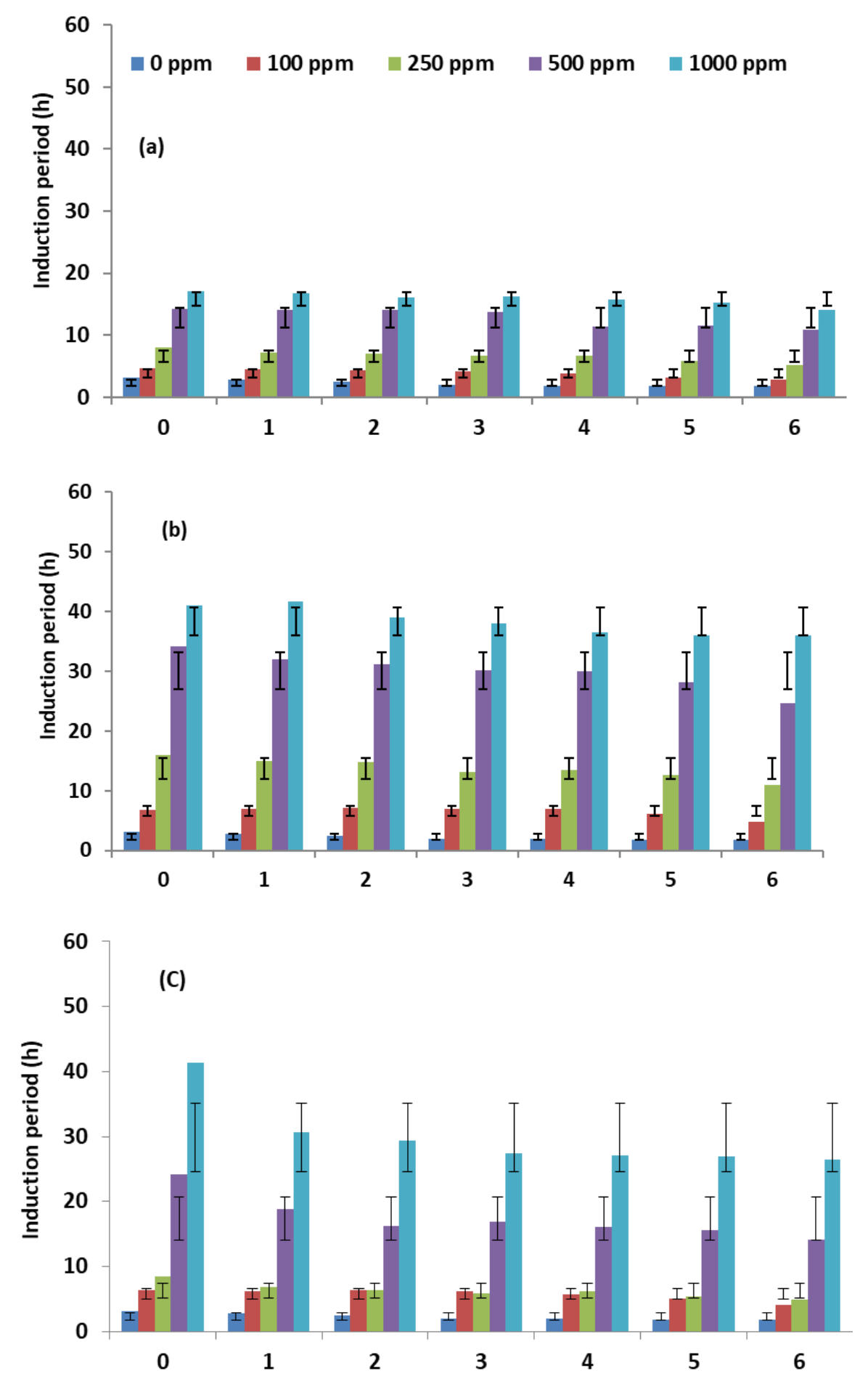


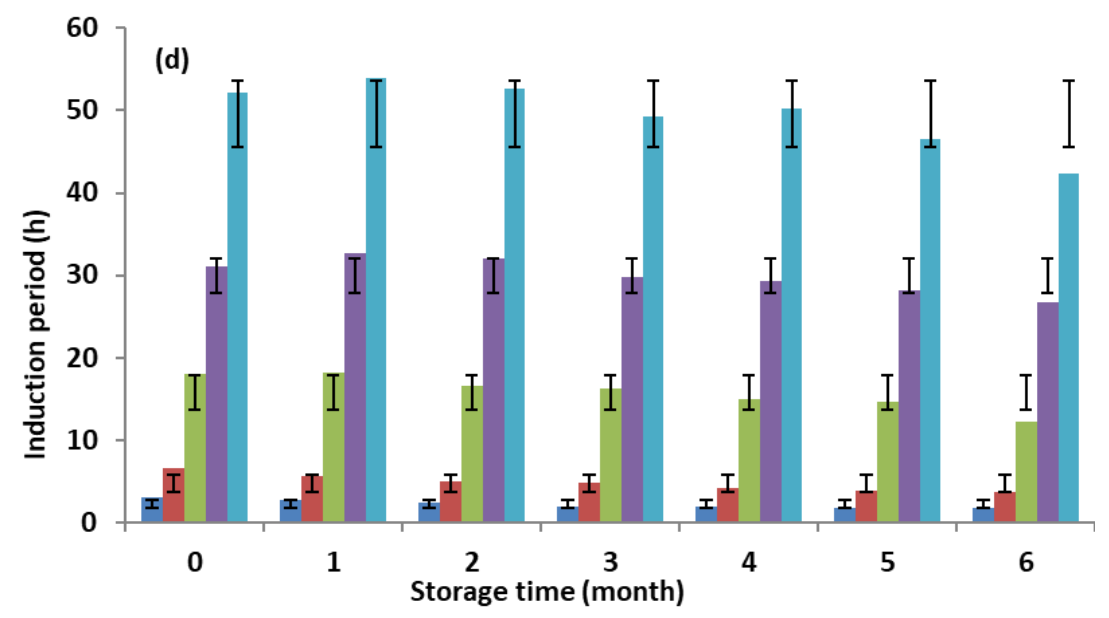

Fig. 3. Induction period of WCO biodiesel treated with BHT (a), BHA (b),TBHQ (c), and PG (d) at different concentrations $(100,250,500$, and $1000 \mathrm{ppm})$. Storage conditions: room temperature (21 ${ }^{\circ} \mathrm{C}$ ), sample bottle, sealed tight, and storage time of 6 months

In general, the induction periods of WCO biodiesel increased with increasing antioxidant concentration. The induction period notably increased from zero stage after adding more than 100 ppm antioxidants. However, all the antioxidants containing biodiesel fuel samples degraded remarkably based on the induction period parameter over storage for 6 months in the dark at room temperature. Table 7 shows the induction period decrease as indicated by a decrease of $18.12 \%$ to $39.13 \%$ (BHT), $34.44 \%$ to $41.73 \%$ (TBHQ), $13.70 \%$ to $29.41 \%$ (BHA) and $13.82 \%$ to $44.69 \%$ (PG) (Table 7). However, above $6 \mathrm{~h}$ induction periods were observed in the cases of 500 and $1000 \mathrm{ppm}$ concentrations for BHT and TBHQ. BHA and PG showed the same result at $250 \mathrm{ppm}$ concentration after a significant decrease over six months (Fig. 3).

Table 7. Decrease in the Induction Period (IP) Values of WCO Biodiesel with $\mathrm{BHT}, \mathrm{TBHQ}, \mathrm{BHA}$, and $\mathrm{PG}$ at Various Concentrations during Storage at Room Temperature for 6 Months

\begin{tabular}{|c|c|c|}
\hline Antioxidant & Concentration $(\mathrm{ppm})$ & IP Decrease $(\%)$ \\
\hline \multirow{4}{*}{ BHT } & 100 & 39.13 \\
\cline { 2 - 3 } & 250 & 36.25 \\
\cline { 2 - 3 } & 500 & 23.94 \\
\cline { 2 - 3 } & 1000 & 18.12 \\
\cline { 2 - 3 } & 100 & 29.41 \\
\cline { 2 - 3 } & 250 & 31.25 \\
\hline \multirow{4}{*}{ BHA } & 500 & 28.07 \\
\hline \multirow{4}{*}{ TBHQ } & 1000 & 13.70 \\
\cline { 2 - 3 } & 100 & 34.44 \\
\cline { 2 - 3 } & 250 & 41.66 \\
\hline \multirow{5}{*}{ PG } & 500 & 41.73 \\
\cline { 2 - 3 } & 1000 & 36.23 \\
\cline { 2 - 3 } & 100 & 44.69 \\
\cline { 2 - 3 } & 250 & 33.13 \\
\hline
\end{tabular}


PG achieved the maximum induction periods at $1000 \mathrm{ppm}$ antioxidant concentration in every month of experiments periodically for 6 months of storage time, followed by TBHQ, BHA, and BHT at the same conditions. At lower concentrations (100 to $500 \mathrm{ppm}$ ) of phenolic commercial antioxidant additive, the order of improvement in the induction periods did not change. Over the 6 months storage periods, PG, BHA, and TBHQ were the most efficient antioxidants. TBHQ and BHA increased the oxidative stability of WCO biodiesel at all concentrations. The effectiveness of used antioxidants at lower concentrations (100 to $500 \mathrm{ppm}$ ) were in the following order BHT $<\mathrm{TBHQ}<\mathrm{BHA}<\mathrm{PG}$ for increasing oxidative stability of WCO biodiesel. A similar trend of antioxidant effectiveness order (BHT < TBHQ < BHA < PG) has been observed by Soh-KheangLoh et al. (2006). In this research, only PG and BHA could easily meet $8 \mathrm{~h}$ oxidation stability at lower concentration $250 \mathrm{ppm}$ during the storage period. Yang et al. (2013) studied the influences of TBHQ, PG, PY, BHA, BHT at $3000 \mathrm{ppm}$ concentration on the oxidation stability of soybean biodiesel and found that the synthetic antioxidants are more effective in the rank order as $\mathrm{PY}>\mathrm{TBHQ}>\mathrm{PG}>\mathrm{BHA}>\mathrm{BHT}$. Suraj et al. (2019) observed that 250 ppm TBHQ meet biodiesel fuel blend stock for middle distillate fuels standard (ASTM D4625-16e1 (2016)) after 100 days of storage.

Phenolic antioxidant suppresses the oxidation reaction because its active hydroxyl group can provide a proton and interrupt the propagation of peroxide radical. Antioxidant capabilities of phenolic compounds are closely related to the number of $\mathrm{OH}$ groups in an aromatic ring and structure (e.g., steric hindrance), electronic behavior of the ring substituent present, and polarity of the solvent. Figure 1 shows that BHT, TBHQ, BHA, and PG have a minimum of two different functional groups in their aromatic ring. PG molecules have three $\mathrm{OH}$ groups and TBHQ molecules possess two $\mathrm{OH}$ groups connected to the aromatic ring structure at different positions; BHT and BHA hold one $\mathrm{OH}$ group linked to the aromatic ring body. When phenolic antioxidants were investigated, their antioxidative capabilities were found to be related to the number of phenolic groups occupying 1,2 or 1,4 positions in the aromatic ring, and also associated with the size and electronic behaviour of the ring substituent present (Liang et al. 2006; de Guzman et al. 2009). PG, TBHQ, and BHA have electron-withdrawing groups at 1,4 position of the aromatic ring, and BHT has an electron-donating group at the same place. The release of a proton to instigate for the making of a quinone configuration is unlikely due to the electrondonating group in the para position in BHT. An electron-withdrawing group (COOR) in PG provides more favor to release proton and delay propagation in the oxidation of FAME. $\mathrm{OR}$ and $\mathrm{OH}$ are weaker electron-withdrawing groups than COOR. That's why BHA and TBHQ are less reactive antioxidants than PG. At higher concentrations, TBHQ is more effective than BHA because BHA has OMe, which is a weaker electron-withdrawing group at 1,4 position than the relatively stronger $\mathrm{OH}$ functional group of TBHQ present at the same place. The relatively low volatile character of BHT and TBHQ is another issue for reduced antioxidant performance (Liang et al. 2006; Karavalakis and Stournas 2010). A significant amount of BHT and TBHQ preservatives may be evaporated during the initial parts of the Rancimat experiment under the operating condition of $110{ }^{\circ} \mathrm{C}$ heating block temperature and $10 \mathrm{~L} / \mathrm{h}$ constant airflow rate for $24 \mathrm{~h}$. (Liang et al. 2006). The comparison of the present study with the previous works is indicated in Table 8. 
Table 8. Comparison of Antioxidant Effect on Oxidation Stability of Biodiesel

\begin{tabular}{|c|c|c|c|c|c|}
\hline $\begin{array}{l}\text { Biodiesel } \\
\text { Feedstock }\end{array}$ & Antioxidant & $\begin{array}{c}\text { Storage } \\
\text { Time } \\
\text { (month) }\end{array}$ & $\begin{array}{l}\text { Investigated } \\
\text { Parameter }\end{array}$ & $\begin{array}{c}\text { Antioxidant } \\
\text { Effectiveness } \\
\text { Order } \\
\end{array}$ & Reference \\
\hline $\begin{array}{c}\text { Used palm } \\
\text { oil }\end{array}$ & $\begin{array}{c}\text { Vitamin E, } \\
\text { BHT, TBHQ, } \\
\text { BHA, and PG }\end{array}$ & 1 & Induction period & $\begin{array}{c}\mathrm{PG}>\mathrm{BHA}>\mathrm{TBHQ}> \\
\mathrm{BHT}>\mathrm{Vitamin} \mathrm{E}\end{array}$ & $\begin{array}{c}\text { (Loh et al. } \\
\text { 2006) }\end{array}$ \\
\hline $\begin{array}{c}\text { Waste } \\
\text { cooking oil }\end{array}$ & - & 2.43 & $\begin{array}{c}\text { Density, } \\
\text { kinematics } \\
\text { viscosity, acid } \\
\text { value, flash point, } \\
\text { and water } \\
\text { content }\end{array}$ & - & $\begin{array}{c}\text { (Khalid et al. } \\
\text { 2014) }\end{array}$ \\
\hline Soybean oil & Curcumin & - & Induction period & - & $\begin{array}{c}\text { (Santos et al. } \\
\text { 2019) }\end{array}$ \\
\hline $\begin{array}{c}\text { Waste } \\
\text { cooking oil }\end{array}$ & $\begin{array}{c}\text { Turmeric, } \\
\text { cinnamon, } \\
\text { black pepper, } \\
\text { Red bell } \\
\text { pepper, } \\
\text { watermelon } \\
\text { seed } \\
\end{array}$ & - & Induction period & $\begin{array}{c}\text { Turmeric }>\text { red bell } \\
\text { pepper>black } \\
\text { pepper }> \\
\text { cinnamon }>\text { water } \\
\text { melon seed }\end{array}$ & $\begin{array}{c}\text { (Nagarajan \& } \\
\text { Narayanasamy } \\
\text { 2020) }\end{array}$ \\
\hline $\begin{array}{l}\text { Pongamia- } \\
\text { pinata }\end{array}$ & Ginger extract & - & Induction period & - & $\begin{array}{l}\text { (Devi et al. } \\
\text { 2017) }\end{array}$ \\
\hline $\begin{array}{l}\text { Calophyllum } \\
\text { inophyllum }\end{array}$ & $\begin{array}{c}\text { PY, BHT, } \\
\text { TBHQ, BHA, } \\
\text { and PG }\end{array}$ & 3.5 & $\begin{array}{c}\text { kinematics } \\
\text { viscosity, acid } \\
\text { value, and } \\
\text { Induction period }\end{array}$ & $\begin{array}{c}\text { TBHQ }>\text { PG }>\text { PY> } \\
\text { BHT>BHA (for } \\
\text { B20) }\end{array}$ & $\begin{array}{c}\text { (Shameer \& } \\
\text { Ramesh 2017) }\end{array}$ \\
\hline $\begin{array}{l}\text { Pongamia, } \\
\text { Jatropha oil }\end{array}$ & Pyrogallol (PY) & - & Induction period & - & $\begin{array}{c}\text { (Kumar et al. } \\
\text { 2018) }\end{array}$ \\
\hline Camelina & $\begin{array}{l}\mathrm{BHT}, \mathrm{TBHQ}, \\
\mathrm{BHA} \text {, and } \mathrm{PG}\end{array}$ & 12 & $\begin{array}{c}\text { Induction period, } \\
\text { PV }\end{array}$ & $\begin{array}{c}\text { TBHQ }>\text { PG }>\text { BHT }> \\
\text { BHA }\end{array}$ & $\begin{array}{l}\text { (J. Yang et al. } \\
\text { 2017) }\end{array}$ \\
\hline $\begin{array}{l}\text { Karanja, } \\
\text { Neem, and } \\
\text { Jatropha }\end{array}$ & $\begin{array}{l}\text { PY, BHT, } \\
\text { TBHQ, BHA, } \\
\text { and PG }\end{array}$ & - & Induction period & $\begin{array}{c}\mathrm{PY}>\mathrm{PG}>\mathrm{BHA}> \\
\mathrm{BHT}>\mathrm{TBHQ}\end{array}$ & $\begin{array}{c}\text { (Agarwal et al. } \\
\text { 2015) }\end{array}$ \\
\hline Soybean oil & $\begin{array}{l}\mathrm{BHT}, \mathrm{TBHQ}, \\
\text { and } \mathrm{BHA}\end{array}$ & - & Induction period & $\mathrm{BHA}>\mathrm{TBHQ}>\mathrm{BHT}$ & $\begin{array}{l}\text { (Maia et al. } \\
\text { 2011) }\end{array}$ \\
\hline $\begin{array}{c}\text { Tallow oil, } \\
\text { Soybean oil, } \\
\text { and Canola } \\
\text { oil }\end{array}$ & $\begin{array}{c}\text { Tocopherol, } \\
\text { PY, BHT, } \\
\text { TBHQ, BHA, } \\
\text { and PG }\end{array}$ & 12 & $\begin{array}{l}\text { Induction period } \\
\text { and acid value } \\
\text { (random } \\
\text { analysis) }\end{array}$ & $\begin{array}{c}\mathrm{PY}>\mathrm{TBHQ}>\mathrm{PG}>\mathrm{B} \\
\mathrm{HA}> \\
\mathrm{BHT}>\mathrm{Tocopherol}\end{array}$ & $\begin{array}{l}\text { (Yang et al. } \\
\text { 2013) }\end{array}$ \\
\hline $\begin{array}{c}\text { Commercial } \\
\text { biodiesel }\end{array}$ & $\begin{array}{l}\mathrm{PY}, \mathrm{BHT}, \mathrm{BHA}, \\
\text { and } \mathrm{PG}\end{array}$ & 2 & $\begin{array}{l}\text { Induction period, } \\
\text { viscosity, and } \\
\text { acid value }\end{array}$ & $\begin{array}{c}\text { PY>PG> } \\
\text { BHT }>\text { BHA (For } \\
\text { Blended B7-B20) }\end{array}$ & $\begin{array}{c}\text { (Karavalakis et } \\
\text { al. 2011) }\end{array}$ \\
\hline Soybean oil & $\begin{array}{c}\text { BHT, TBHQ, } \\
\text { and BHA } \\
\text { (synthetic) } \\
\text { Rosemary, } \\
\text { oregano, and } \\
\text { basil (natural) }\end{array}$ & - & Induction period & $\begin{array}{l}\text { TBHQ>natural } \\
\text { antioxidant } \\
\text { (Rosemary, } \\
\text { oregano, \& basil) } \\
\text { > BHA> BHT }\end{array}$ & $\begin{array}{l}\text { (Ferrari et al. } \\
2005)\end{array}$ \\
\hline $\begin{array}{l}\text { Karanja } \\
\text { seed oil }\end{array}$ & TBHQ & 4 & $\begin{array}{l}\text { Induction period, } \\
\text { viscosity, density, } \\
\text { acid value, } \\
\text { peroxide value }\end{array}$ & 1000 ppm TBHQ & $\begin{array}{c}\text { (Suraj et al. } \\
\text { 2019) }\end{array}$ \\
\hline Commercial & $\mathrm{PA}, \mathrm{BHT}$, & - & Induction period & $\mathrm{PG}>\mathrm{TBHQ}>\mathrm{BHA}>$ & (Karavalakis \& \\
\hline
\end{tabular}




\begin{tabular}{|c|c|c|c|c|c|}
\hline biodiesel & $\begin{array}{c}\text { TBHQ, BHA, } \\
\text { and PG }\end{array}$ & & & BHT & Stournas 2010) \\
\hline Waste & $\begin{array}{c}\text { BHT, TBHQ, } \\
\text { BHA, and PG }\end{array}$ & 6 & $\begin{array}{c}\text { Induction period, } \\
\text { viscosity, density, } \\
\text { acid value, and } \\
\text { fatty acid methyl } \\
\text { ester composition }\end{array}$ & $\begin{array}{c}\text { PG>TBHQ>BHA> } \\
\text { BHT (at higher } \\
\text { conc.); PG>BHA> } \\
\text { TBHQ> BHT (at a } \\
\text { lower } \\
\text { concentration) }\end{array}$ & This study \\
\hline
\end{tabular}

Acid value

Fatty acid methyl esters containing more poly unsaturation double bonds in the structure are more prone to oxidation to produce primary products hydroperoxides. These primary products mostly decompose and form secondary oxidation products at suitable conditions (Suraj et al. 2019). The secondary oxidation products are usually alcohols and aldehydes such as propanal, hexanal, etc. Secondary products are very reactive and easily oxidized into low molecular organic acids such as formic acid, acetic acid, propionic acid, caproic acid, etc. (Kamal-Eldin and Pokorny 2005; Dridi et al. 2016). As a result, the acid value increases. The acid value is a crucial parameter of the secondary oxidation process of long-term biodiesel storage (Ezeanyanaso et al. 2012). Figure 4 shows the effects of antioxidant concentration in WCO biodiesel fuel samples on acid values under long term storage.


Fig. 4. Acid value of WCO biodiesel treated with $B H T$ (a), BHA (b), TBHQ (c), and PG (d) at different concentrations $(100,250,500$, and $1000 \mathrm{ppm})$. Storage conditions: room temperature $\left(21^{\circ} \mathrm{C}\right)$, sample bottle, sealed tight, and storage time of 6 months

The acid value increased for all the experimental WCO biodiesel fuel samples by reason of the secondary oxidation proceeding on the fatty acid methyl ester chain. A higher concentration (500 and $1000 \mathrm{ppm}$ ) of antioxidants containing samples could meet the EN or ASTM standard values within the 6 months of storage time at $21^{\circ} \mathrm{C}$. PG showed only a 
$22 \%$ increase in acid value at $1000 \mathrm{ppm}$ concentration after the storage period. The higher rate of increasing acid value of test samples in lower concentrations (100 and $250 \mathrm{ppm}$ ) and fresh biodiesel samples at stored conditions was due to a higher rate of secondary oxidation. After two months of storage periods at $43{ }^{\circ} \mathrm{C}$, Karanja biodiesel without antioxidant failed to meet the biodiesel standard (ASTM D4625-16e1 (2016)) (Suraj et al. 2019). The acid value increased over 10 weeks of storage time for B7, B10, and B20 with synthetic antioxidants (BHT, BHA, PG, PY, and TBHQ), but all values were within the limit of the standard according to Karavalakis et al. (2011).

\section{Kinematic viscosity}

Higher viscosity and acid value cause serious trouble relative to engine performance and fuel supply systems. For commercial utilization of biodiesel, it would be necessary to keep viscosity and acid value within the limit of standard specifications. It is essential to observe kinematic viscosity during the storage period. In the storage time, kinematic viscosity increases periodically during storage time because hydroperoxides decompose, and finally, it will create polymeric products by oxidation (Suraj et al. 2019). Sometimes fatty acid methyl esters lead to the isomerization reaction of double bonds in a long-chain structure such as cis to trans, enlarging kinematic viscosity. Figure 5 shows the effects of antioxidant concentration in WCO biodiesel fuel samples on viscosity under long term storage.
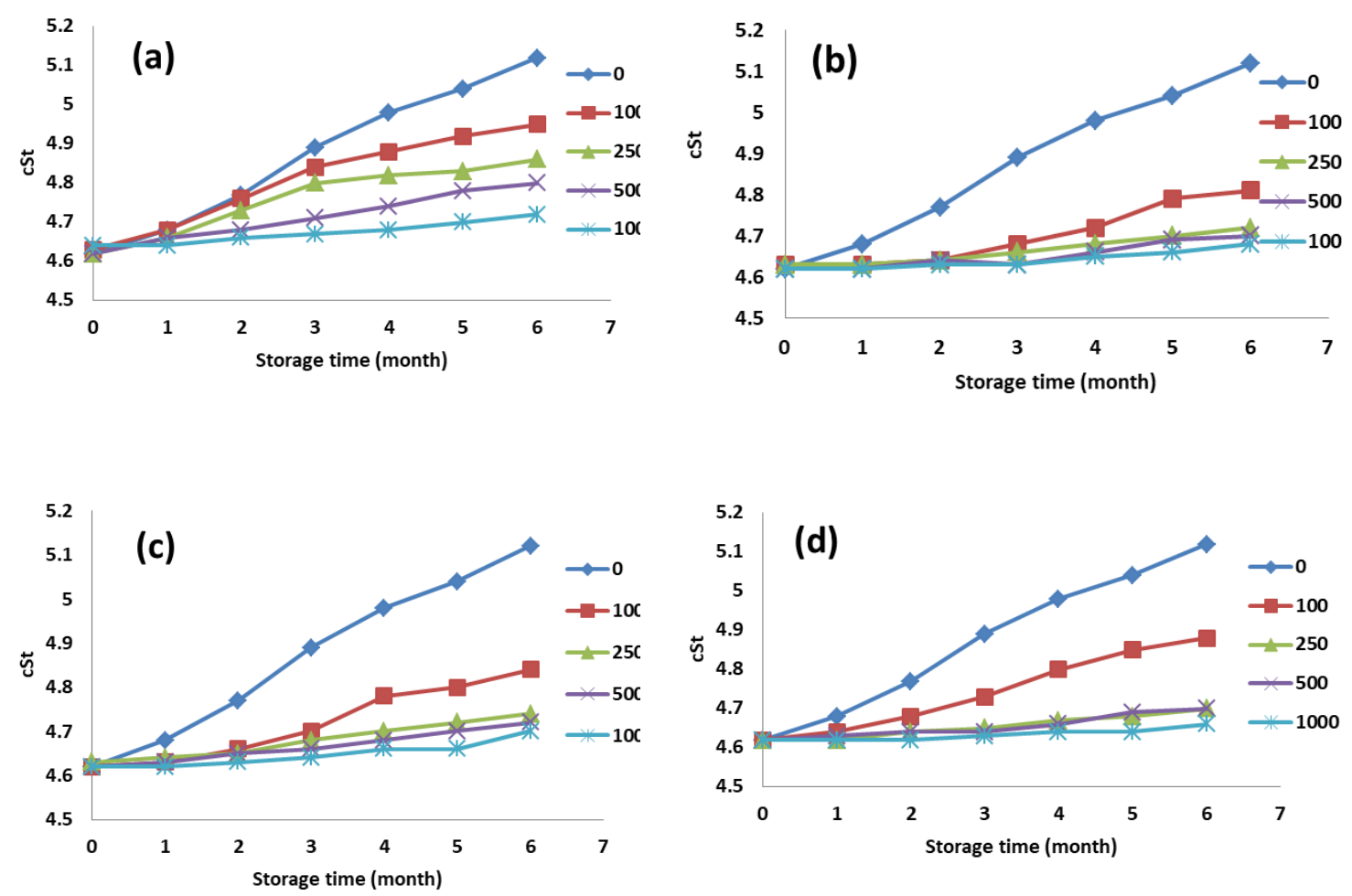

Fig. 5. Viscosity of WCO biodiesel treated with BHT (a), BHA (b), TBHQ (c), and PG (d) at different concentrations $(100,250,500$, and $1000 \mathrm{ppm})$. Storage conditions: room temperature $\left(21^{\circ} \mathrm{C}\right)$, sample bottle, sealed tight, and storage time of 6 months 
Kinematic viscosity increased rapidly in the fresh WCO biodiesel sample compared to other antioxidant containing test samples during the storage period. It is expected that a slower rate of increasing the kinematic viscosity of test samples would be observed during the storage period with the increasing antioxidant concentration, which decelerates secondary oxidation and polymerization reactions. All the WCO biodiesel samples with antioxidants easily met the biodiesel standard limits for viscosity even after 6 months of storage, while fresh WCO biodiesel fuel sample exceeded the highest limit set by the EN or ASTM standard in 6 months of storage period. In the case of fuel samples stored at 43 ${ }^{\circ} \mathrm{C}$, neat Karanja biodiesel crossed the maximum limit set by the ASTM standard specifications (ASTM D4625-16e1 (2016)) within 4 months of storage (Suraj et al. 2019). Karavalakis et al. (2011) reported that viscosity increases over 10 weeks of storage time for B10 with synthetic antioxidants (BHT, BHA, PG, PY, and TBHQ); all values are within the limit of standard.

\section{Density}

Figure 6 shows the effects of antioxidant concentration in WCO biodiesel fuel samples on density under long term storage.
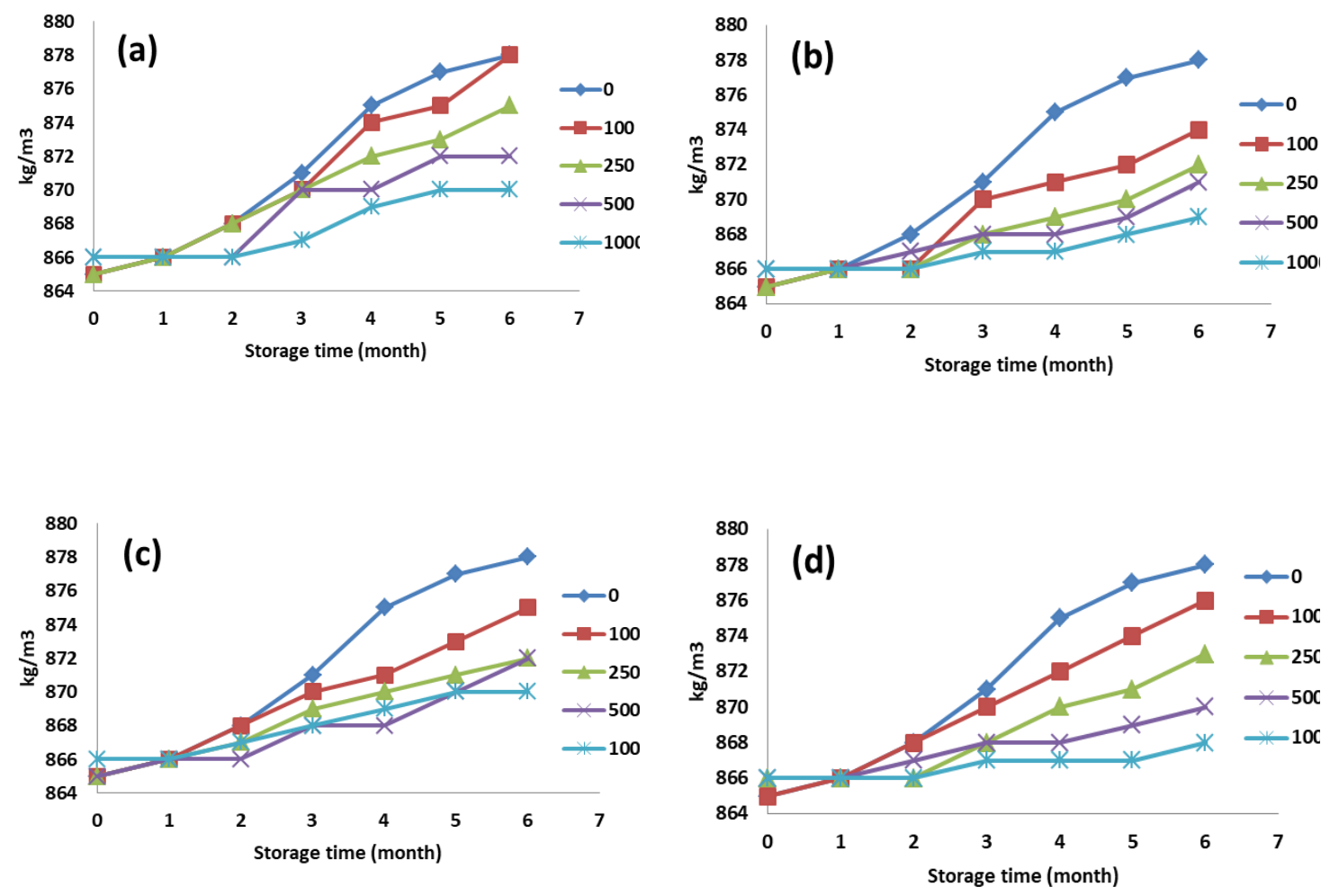

Fig. 6. Density of WCO biodiesel treated with BHT (a), BHA (b), TBHQ (c), and PG (d) at different concentrations $(100,250,500$, and $1000 \mathrm{ppm})$. Storage conditions: room temperature $\left(21^{\circ} \mathrm{C}\right)$, sample bottle, sealed tight, and storage time of 6 months

As discussed previously, unsaturated fatty acids can quickly form high molecular weight compounds during the oxidation reactions at suitable conditions. These nonrequired compounds are formed by polymerization reactions in which low molecular 
compounds are combined for the period of the storage condition of biodiesel fuel samples. As a result of polymerization reactions in biodiesel, the density remarkably increased for all the investigated fuel samples during the storage period (Khalid et al. 2014). From Fig. 6 , the density of the fresh WCO biodiesel fuel samples was significant for storage condition. All the WCO biodiesel fuel samples were within European Standard (EN 14214 (2012)) value even after 6 months of storage period. Suraj et al. (2019) has provided the data of all the test fuel samples' densities well within EN standard specifications for lower unsaturated FAME containing Karanja biodiesel even after 1 year of storage period at 43 ${ }^{\circ} \mathrm{C}$ test conditions.

\section{CONCLUSIONS}

1. Waste cooking oil biodiesel exhibited $3.12 \mathrm{~h}$ of oxidative stability, according to EN14112. Propyl gallate (PG) was the most effective antioxidant in waste cooking oil (WCO) biodiesel, followed by butylated hydroxyanisole (BHA) and tert-butyl hydroquinone (TBHQ), whereas butylated hydroxytoluene (BHT) was the least effective for enhancing oxidation stability in the 6 months storage.

2. A concentration of $500 \mathrm{ppm}$ of all antioxidant species dynamically reached the target value of the induction period $(8 \mathrm{~h})$. BHA and PG showed an above $11 \mathrm{~h}$ induction period for 6 months of storage at $250 \mathrm{ppm}$ concentration. Thus, WCO biodiesel could be a competitive alternative to diesel fuel from the point of view long term storage with PG antioxidants.

3. 1000 ppm concentration PG, BHA, and tert-butyl hydroquinone (TBHQ) showed the most effective result in fatty acid methyl ester (FAME) composition. The percentages $96.76 \%, 95.66 \%$, and $94.33 \%$ of FAME remained unoxidized at the end of the storage period by the antioxidant PG, BHA, and TBHQ. TBHQ and BHA showed similar results at $1000 \mathrm{ppm}$.

4. The acid value of all the antioxidant containing biodiesel fuel samples were capable of meeting the biodiesel standard within the 6 months of storage time at a higher level concentration (500 and $1000 \mathrm{ppm}$ ) of all investigated antioxidants.

5. In the case of kinematic viscosity and density of all the biodiesel samples with antioxidants showed the acceptable results even after 6 months of storage period according to biodiesel standard specification (EN or ASTM). Acid value, kinematic viscosity, and density increase with the decrease of oxidation stability of WCO biodiesel during the storage period.

\section{ACKNOWLEDGMENTS}

This work is financially supported by the Institute of Fuel Research and Development (IFRD), the Bangladesh Council of Scientific and Industrial Research (BCSIR), and the Bangabandhu Science and Technology Fellowship Trust under the Ministry of Science and Technology, Peoples Republic of Bangladesh. 


\section{Author Contributions}

Conceptualization: Mosharof Hossain; methodology: Mohammad Shah Jamal., Shah Mohammad Asaduzzaman Sujan; software: Shah Mohammad Asaduzzaman Sujan, Mohammad Shah Jamal; validation: Mosharof Hossain, Md.Shahriar Chowdhury; formal analysis: Mohammad Shah Jamal, Mosharof Hossain; investigation: Kuaanan Techato, Abu Naieum Muhammad Fakhruddin; resources: Mohammad Shah Jamal; data curation: Mosharof Hossain; writing — original draft preparation Shah Mohammad Asaduzzaman Sujan, Mohammad Shah Jamal; writing-review and editing: Mosharof Hossain, Md.Shahriar Chowdhury; visualization: KuaananTechato; supervision: A. N. M.

Fakhruddin; project administration: Abu Naieum Muhammad Fakhruddin; funding acquisition: KuaananTechato.

\section{Conflicts of Interest}

The authors declare no conflict of interest.

\section{REFERENCES CITED}

Agarwal, A. K., Khurana, D., and Dhar, A. (2015). "Improving oxidation stability of biodiesels derived from Karanja, Neem and Jatropha: Step forward in the direction of commercialisation," Journal of Cleaner Production 107, 646-652. DOI: 10.1016/j.jclepro.2015.05.055

Alam, M., Rana, S., Haque, M., Hossain, M., Sujan, S., and Jamal, M. (2017). "Biodiesel from non-edible Karanja seed oil," Bangladesh Journal of Scientific and Industrial Research 52(1), 15-20. DOI: 10.3329/bjsir.v52i1.32066

ASTM D445 - 19a (2019). "Standard test method for kinematic viscosity of transparent and opaque liquids (and calculation of dynamic viscosity)," ASTM International, West Conshohocken, USA.

ASTM D4052 - 18a (2018). "Standard test method for density, relative density, and API gravity of liquids by digital density meter," ASTM International, West Conshohocken, USA.

ASTM D664 - 18e2 (2018). "Standard test method for acid number of petroleum products by potentiometric titration," ASTM International, West Conshohocken, USA.

ASTM D97 - 17b (2017). "Standard test method for pour point of petroleum products," ASTM International, West Conshohocken, USA.

ASTM D4625 - 16e1a (2016). "Standard specification for biodiesel fuel blend stock (B100) for middle distillate fuels," ASTM International, West Conshohocken, USA.

ASTM D240 - 19 (2000). "Standard test method for heat of combustion of liquid hydrocarbon fuels by bomb calorimeter," ASTM International, West Conshohocken, USA.

ASTM D93 - 20 (1980). "Standard test methods for flash point by Pensky-Martens closed cup tester," ASTM International, West Conshohocken, USA.

Atabani, A. E., Silitonga, A. S., Badruddin, I. A., Mahlia, T., Masjuki, H., and Mekhilef, S. (2012). "A comprehensive review on biodiesel as an alternative energy resource and its characteristics," Renewable and Sustainable Energy Reviews 16(4), 20702093. DOI: 10.1016/j.rser.2012.01.003 
Balat, M., and Balat, H. (2010). "Progress in biodiesel processing," Applied Energy, 87(6), 1815-1835. DOI: 10.1016/j.apenergy.2010.01.012

Bondioli, P., Gasparoli, A., Lanzani, A., Fedeli, E., Veronese, S., and Sala, M. (1995). "Storage stability of biodiesel," Journal of the American Oil Chemists' Society 72(6), 699-702. DOI:10.1007/BF02635658

de Guzman, R., Tang, H., Salley, S., and Ng, K. S. (2009). "Synergistic effects of antioxidants on the oxidative stability of soybean oil-and poultry fat-based biodiesel," Journal of the American Oil Chemists' Society 86(5), 459. DOI: 10.1007/s11746-0091373-8

Demirbas, A. (2009). "Progress and recent trends in biodiesel fuels," Energy Conversion and Management 50(1), 14-34. D10.1016/j.enconman.2008.09.001

Devi, A., Das, V. K., and Deka, D. (2017). "Ginger extract as a nature based robust additive and its influence on the oxidation stability of biodiesel synthesized from nonedible oil," Fuel 187, 306-314. DOI:10.1016/j.fuel.2016.09.063

Dridi, W., Toutain, J., Sommier, A., Essafi, W., Gargouri, M., Leal-Calderon, F., and Cansell, M. (2016). "Characterization of lipid oxidation in plant oils by microcalorimetry," Food Chemistry 197, 709-713.DOI:10.1016/j.foodchem.2015.11.040

EN 14214 (2012). "Liquid petroleum products. Fatty acid methyl esters (FAME) for use in diesel engines and heating applications. Requirements and test methods," ASTM International, West Conshohocken, USA.

EN14103 (2011). "Fat and oil derivatives. Fatty acid methyl esters (FAME). Determination of ester and linolenic acid methyl ester contents," European Committee for Standardization, Brussels, Belgium.

EN 14112 (2012). "Fat and oil derivatives - fatty acid methyl esters (FAME) — determination of oxidation stability (accelerated oxidation test)," British Standards Institution, West Conshohocken.

Ezeanyanaso, C., Ajibola, V., Agbaji, E., Okonkwo, E., Okunola, O., and Alhassan, Y. (2012). "Comparative studies of oxidative stability properties of biodiesel produced from Azadirachta indica and Hevea brasiliensis seeds," Agric. Sci. 2(5), 195-206.

Ferrari, R. A., Oliveira, V. d. S., and Scabio, A. (2005). "Oxidative stability of biodiesel from soybean oil fatty acid ethyl esters," Scientia Agricola 62(3), 291-295. DOI: 10.1590/S0103-90162005000300014

Frankel, E. N. (2014). Lipid oxidation: Elsevier.

Gupta, P., Kumar, R., Panesar, B., and Thapar, V. (2007). "Parametric studies on bio-diesel prepared from rice bran oil," Agricultural Engineering International: Int. Com Agr Eng., 1-12.

Hossain, M., Sujan, S., Hossain, M., and Jamal, M. (2014). "Extraction of crude rubber oil from rubber seed and production of biodiesel," Journal of Biofuels 5(1), 16-23.

Hossain, M., Sujan, S., and Jamal, M. (2013). "Antioxidant effect on oxidation stability of blend fish oil biodiesel with vegetable oil biodiesel and petroleum diesel fuel," International Journal of Renewable Energy Development 2(2), 75-80. DOI: 10.14710/ijred.2.2.75-80

Hossain, M., Toba, M., Abe, Y., Mochizuki, T., and Yoshimura, Y. (2010). "Effect of antioxidant species on oxidation stability of fish oil biodiesel," Journal of the Japan Petroleum Institute 53(6), 365-366. DOI :10.1627/jpi.53.365

Kafuku, G., and Mbarawa, M. (2013). "Influence of fatty acid profiles during supercritical transesterification of conventional and non-conventional feedstocks: A review," American Journal of Analytical Chemistry 4(09), 469. DOI: 
10.4236/ajac.2013.49060

Kamal-Eldin, A., and Pokorny, J. (2005). Analysis of Lipid Oxidation, AOCS Publishing.

Karavalakis, G., Hilari, D., Givalou, L., Karonis, D., and Stournas, S. (2011). "Storage stability and ageing effect of biodiesel blends treated with different antioxidants," Energy 36(1), 369-374. DOI: 1016/j.energy.2010.10.029

Karavalakis, G., and Stournas, S. (2010). "Impact of antioxidant additives on the oxidation stability of diesel/biodiesel blends, " Energy \& Fuels 24(6), 3682-3686. DOI: $10.1021 / \mathrm{ef} 1004623$

Khalid, A., Azman, N., Zakaria, H., Manshoor, B., Zaman, I. B., Sapit, A., and Leman, A. M. (2014). "Effects of storage duration on biodiesel properties derived from waste cooking oil," Applied Mechanics and Materials 554, 494-499. DOI: 10.4028/www.scientific.net/AMM.554.494

Knothe, G., Gerpen, J., and Krahl, J. (2005). The Biodiesel Handbook: American Oil Chemists', Society (AOCS) Press: Urbana, IL.

Kumar, S., Yadav, K., and Dwivedi, G. (2018). "Impact analysis of oxidation stability for biodiesel \& its blends," Materials Today: Proceedings 5(9), 19255-19261. DOI:10.1016/j.matpr.2018.06.283

Liang, Y. C., May, C. Y., Foon, C. S., Ngan, M. A., Hock, C. C., and Basiron, Y. (2006). "The effect of natural and synthetic antioxidants on the oxidative stability of palm diesel," Fuel 85(5-6), 867-870. DOI: 10.1016/j.fuel.2005.09.003

Loh, S.-K., Chew, S.-M., and Choo, Y.-M. (2006). "Oxidative stability and storage behavior of fatty acid methyl esters derived from used palm oil," Journal of the American Oil Chemists' Society 83(11), 947-952. DOI:10.1007/s11746-006-5051-9

Maia, E. C. R., Borsato, D., Moreira, I., Spacino, K. R., Rodrigues, P. R. P., and Gallina, A. L. (2011). "Study of the biodiesel B100 oxidative stability in mixture with antioxidants," Fuel Processing Technology 92(9), 1750-1755. DOI: 10.1016/j.fuproc.2011.04.028

March, J. (1992). Advanced Organic Chemistry: Reactions, Mechanisms, and Structure, John Wiley \& Sons.

Mittelbach, M., and Gangl, S. (2001). "Long storage stability of biodiesel made from rapeseed and used frying oil," Journal of the American Oil Chemists' Society 78(6), 573-577. DOI:10.1007/s11746-001-0306-z

Monyem, A., Canakci, M., and Van Gerpen, J. H. (2000). "Investigation of biodiesel thermal stability under simulated in-use conditions," Applied Engineering in Agriculture 16(4), 373. DOI: 10.13031/2013.5213

Nagarajan, J., and Narayanasamy, B. (2020). "Effects of natural antioxidants on the oxidative stability of waste cooking oil biodiesel," Biofuels.

DOI:10.1080/17597269.2019.1711320

Paligová, J., Joríková, L., and Cvengroš, J. n. (2008). "Study of FAME stability," Energy \& Fuels 22(3), 1991-1996. DOI:10.1021/ef7007419

Ramaraju, A., and Kumar, T. A. (2011). "Biodiesel development from high free fatty acid punnakka oil," ARPN Journal of Engineering and Applied Sciences 6(4), 1-6.

Saluja, R. K., Kumar, V., and Sham, R. (2016). "Stability of biodiesel-A review," Renewable and Sustainable Energy Reviews 62, 866-881. DOI: 10.1016/j.rser.2016.05.001

Santos, M. N., de Souza, E. F., Ramos, T. C. P. M., Cavalheiro, A. A., Fiorucci, A. R., and da Silva, M. S. (2019). "Effect of curcumin natural antioxidant on oxidative stability of commercial biodiesels from different raw materials," Orbital: The 
Electronic Journal of Chemistry 11(4), 239-245. DOI: 10.17807/orbital.v11i4.1225

Shahid, E. M., and Jamal, Y. (2011). "Production of biodiesel: A technical review," Renewable and Sustainable Energy Reviews 15(9), 4732-4745. DOI:

10.1016/j.rser.2011.07.079

Shameer, P. M., and Ramesh, K. (2017). "Influence of antioxidants on fuel stability of Calophyllum inophyllum biodiesel and RSM-based optimization of engine characteristics at varying injection timing and compression ratio," Journal of the Brazilian Society of Mechanical Sciences and Engineering 39(11), 4251-4273. DOI: 10.1007/s40430-017-0884-8

Simkovsky, N., and Ecker, A. (1999). "Effect of antioxidants on the oxidative stability of rapeseed oil methyl esters," Erdol Erdgas Kohle 115, 317-317.

Suraj, C., Krishnasamy, A., and Sundararajan, T. (2019). "Investigations on gradual and accelerated oxidative stability of karanja biodiesel and biodiesel-diesel blends," Energy \& Fuels 33(9), 9196-9204. DOI: 10.1021/acs.energyfuels.9b01678

Tang, H., Wang, A., Salley, S. O., and Ng, K. S. (2008). "The effect of natural and synthetic antioxidants on the oxidative stability of biodiesel," Journal of the American Oil Chemists' Society 85(4), 373-382. DOI: 10.1007/s11746-008-1208-z

Thompson, J., Peterson, C., Reece, D., and Beck, S. (1998). "Two-year storage study with methyl and ethyl esters of rapeseed," Transactions of the ASAE, 41(4), 931. DOI: $10.13031 / 2013.17250$

Viegas, I., Barradas Filho, A. O., Marques, E. P., Pereira, C. F., and Marques, A. L. (2018). "Oxidative stability of biodiesel by mixture design and a four-component diagram," Fuel 219, 389-398. DOI: 10.1016/j.fuel.2018.01.124

Waynick, J. (2005). Characterization of Biodiesel Oxidation and Oxidation Products, National Renewable Energy Laboratory, CRC, Project No. AVFL-2b.

Yang, J., He, Q. S., Corscadden, K., and Caldwell, C. (2017). "Improvement on oxidation and storage stability of biodiesel derived from an emerging feedstock camelina," Fuel Processing Technology 157, 90-98. DOI: 10.1016/j.fuproc.2016.12.005

Yang, Z., Hollebone, B. P., Wang, Z., Yang, C., and Landriault, M. (2013). "Factors affecting oxidation stability of commercially available biodiesel products," Fuel Processing Technology 106, 366-375. DOI: 10.1016/j.fuproc.2012.09.001

Article submitted: November 26, 2020; Peer review completed: February 13, 2021; Revised version received: May 14, 2021; Accepted: May 14, 2021; Published: September 2, 2021.

DOI: $10.15376 /$ biores.16.4.7021-7039 